\title{
Ten Years on: The Exhaustion Principle and the Practice of the Constitutional Court of Kosovo as the Final Authority for Protection of Human Rights
}

\author{
Besfort T. Rrecaj \\ University of Prishtina "Hasan Pristhina", Faculty of Law \\ Bardh Bokshi \\ Constitutional Court of Kosovo, Prishtina
}

Received 12 June 2018 • Revised 10 July 2018 • Accepted 18 July 2018

\begin{abstract}
Ten years after the establishment of the Constitutional Court of Kosovo, this paper aims to examine the concept of exhaustion of legal remedies in Kosovo judicial system where an individual has brought a case claiming violation of human rights guaranteed by the Constitution. The paper will focus on analyzing what constitutes an effective legal remedy including ordinary and extraordinary remedies for the purposes of submitting a constitutional complaint with the Constitutional Court. This work is based on the case-law of the Constitutional Court and tries to explain all legal steps that must be observed before submitting a constitutional complaint regarding exhaustion requirement. Furthermore, it will delve deeper into this concept by distinguishing the importance of formal and substantive exhaustion of legal remedies, the interconnectedness of formal and substantive exhaustion of legal remedies and the distinction between them as developed by the case-law of the Constitutional Court. It will conclude by summarizing main characteristics of the concept of exhaustion of legal remedies in Kosovo as it is established by the practice of the Constitutional Court.
\end{abstract}

Keywords: effective legal remedies, exhaustion of legal remedies, extraordinary legal remedies, formal and substantive exhaustion of legal remedies, the principle of subsidiarity.

\section{Introduction}

Before delving into the topic of exhaustion of legal remedies for the purposes of submitting a constitutional complaint with the Constitutional Court of Kosovo (hereinafter, the Constitutional Court), it is necessary to provide the constitutional and legal background which lay down that requirement. Article 113.7 of the Constitution of Kosovo (hereinafter, the Constitution) (Kosovo Constitution 2008 and its amendments) establishes that individuals must exhaust all legal remedies to their availability before submitting a complaint with the Constitutional Court. This requirement is further confirmed by Article 47.2 of the Law on Constitutional Court which provides that individuals may submit a referral with the Constitutional Court only after they have exhausted all legal remedies provided for by law (Law on the Constitutional Court of Kosovo). The exhaustion of legal remedies ought to mean remedies that are not only available in formal terms but also effective in providing a redress for an individual raising the complaint. Within this concept

(C) Authors. Terms and conditions of Creative Commons Attribution 4.0 International (CC BY 4.0) apply. Correspondence: Besfort T. Rrecaj, University of Prishtina "Hasan Prishtina", Agim Ramadani Str. nn. 1000o, Prishtina, KOSOVO. e-mail: besfort.rrecaj@uni-pr.edu. 
it becomes more a matter of judicial practice to determine which remedy is available and effective rather than just to consider legal remedies provided by law. This standard is established by the European Court of Human Rights (hereinafter, the ECtHR) and applicable in Kosovo. In the following text the requirement of exhaustion of legal remedies will be explained through lenses of judicial practice of the Constitutional Court. Formal and substantive exhaustion of legal remedies will be discussed as well as their meaning which is not so obvious from the wording of Article 113.7 of the Constitution but is rather developed through case-law of the Constitutional Court. Ten years on, it is still building it practice nevertheless, so far it managed to establish some basic principles based on the ECtHR practice in upholding and interpreting basic human rights in Kosovo. The so called balancing test in exhaustion examination was conceived in order to help the Constitutional Court to determine the availability and effectiveness of particular legal remedies. Ultimately this test would determine whether a case will be heard at the Constitutional Court or not when an individual requests direct access to be heard before this court.

2. Establishment of the Constitutional Court, jurisdiction and the individual complaint

The Constitutional Court of Kosovo as the youngest court of such nature in Europe was established after Kosovo declared its independence in 2008. The role of this court was to become a guardian of the Constitutional of Kosovo but it would be set in motion only when requested so by the authorized parties as stipulated in Article 113 of the Constitution of Kosovo. (Constitution of Kosovo) It does not have an ex officio authority to put its machinery in motion. Among authorized parties are individuals claiming concrete violation of human rights guaranteed by the Constitution. This article is applicable to natural as well as legal persons as established duly by the applicable law in Kosovo ${ }^{1}$ (Case No. KI41/o9, Applicant, AAB-RIINVEST L.L.C). The Constitution of Kosovo Chapter VIII and Law on Constitutional Court lay basic foundation and jurisdiction of the Court. In this regard, Article 113.7 of the Constitution authorizes individuals "...to refer violations by public authorities of their individual rights and freedoms guaranteed by the Constitution..." (Constitution of Kosovo). Accordingly, the Constitutional Court ought to represent a legal remedy as a final authority for all those individuals who claim violation of human rights by public authorities.

Although Kosovo aims to become part of the Council of Europe, due to political disagreements over the political status, it has not succeeded in realizing this aim so far. This makes Kosovo a self-contained human rights regime with individuals not being able to hear their cases before a larger and important institutional framework such as the ECtHR. However, in order to avoid this deficiency, drafters of the Constitution of Kosovo took care to provide a larger and more comprehensive human rights protection within this self-contained regime by unilaterally obliging itself to respect main international and European human rights conventions and also by making the practice of the ECtHR as the main reference for public authorities in interpretation of human rights guaranteed by the Constitution. The Constitutional Court by virtue of Articles 22 and 53 of the Constitution is under constitutional obligation to apply the European Convention of Human Rights (hereinafter, the ECHR) ${ }^{2}$, directly in cases involving human rights and fundamental

${ }^{1}$ The case emphasizes that fundamental rights and freedoms set forth in the Constitution are also valid for legal persons to the extent applicable, and that, they too, must fulfill the requirement to exhaust all legal remedies.

${ }^{2}$ Article 22.2 of the Constitution of Kosovo establishes that the European Convention on Human Rights and its protocols are directly applicable in the legal system of Kosovo and that, in case of conflict; it has priority over provisions of laws and other acts of public institutions. 
freedoms and to interpret them consistent with the court decisions of the ECtHR ${ }^{3}$. For these reasons the case-law of the Constitutional Court is replete with references to the case law of the ECtHR with regard to application of the standards and safeguards of fundamental human rights and freedoms. The practice of the ECtHR was main determinant in building up the practice of the Constitutional Court and in this regards it is also reflected in the application of the requirement for exhaustion of legal remedies.

The individual complaints submitted with the Constitutional Court form the so-called subsidiary jurisdiction 4 . This principle is intrinsic of the ECtHR jurisdiction and thus the role of the Constitutional Court is subsidiary to the regular judiciary and other public authorities in Kosovo. The idea behind exhaustion principle lies on assumption that the regular juridical system of the state would provide effective legal remedies to uphold constitutional rights. 5 Within this authority, the Constitutional Court can generally review individual decisions and acts of the regular judiciary and of other public authorities only as to the observance of human rights guaranteed by the constitution.

\section{Formal and substantive exhaustion of legal remedies and the burden of proof}

The question of exhaustion of legal remedies is not as straightforward as it may initially appear because there are several factors that must be taken into account. These factors invariably include the availability and effectiveness of a legal remedy because only legal remedies that are available and effective must be exhausted. Furthermore this concept requires that legal remedies are exhausted in the formal as well as in substantive terms. The formal term of exhaustion of legal remedies requires that the prospective applicants before submitting a constitutional complaint with the Constitutional Court, must follow, a step by step procedure in all instances of the regular courts in Kosovo composed of the Basic Court, the Court of Appeals and the Supreme Court. The Supreme Court deals mainly with extraordinary legal remedies which have their own peculiarities but will be dealt duly as the process of exhaustion is explained 6 (Code of Criminal Procedure of Kosovo No. 04/L-123, Article 435.1).

In this regards, The Constitutional Court adopted the stance of the European Court that exhaustion of legal remedies must be applied with some degree of flexibility and without excessive formalism. 7 The burden of proof lies with the applicant bringing the claim with the

3 Article 53 of the Constitution of Kosovo establishes that human rights and fundamental freedoms guaranteed the Constitution of Kosovo must be interpreted consistent with the case-law of the European Court of Human Rights.

4 It is said subsidiary jurisdiction as opposed to the original jurisdiction of the Constitutional Court as established in paragraphs 2, 3, 4, 5, 6, 8 and 9 of Article 113 of the Constitution of Kosovo. The authorized actors which can engage the original jurisdiction of the Constitutional Court are the Assembly of Kosovo, the President of Kosovo, the Government, the Ombudsperson, the municipalities of Kosovo and the regular judiciary in a so-called incidental control procedure whereby the regular courts have the right to refer question of compatibility of a law with the Constitution when it is raised during the course of regular judicial proceeding.

5 See mutatis mutandis cases KI 41/o9, Applicant AAB-Rïnvest University L.L.C. Prishtina, Constitutional Court Resolution on Inadmissibility of 21 January 2010 and ECtHR case Selmouni vs. France, No. 25803/94, ECtHR, judgment of 28 July 1999.

${ }^{6}$ Article 435.1 of the Code, stipulates that a request for protection of legality shall be considered by the Supreme Court of Kosovo in a session of the panel. Article 436.1 of the same Code stipulates that when deciding on a request for protection of legality the Supreme Court of Kosovo shall confine itself to examining those violations of law which the requesting party alleges in his or her request.

7 In comparison to practice of the ECtHR on the burden of proof see Judgment on the Merits delivered by a Chamber, Dalia $v$. France, No. 26102/95, 19 February 1998. See also Practical Guide on Admissibility 
B. Bokshi \& B. T. Rrecaj - Ten Years on: The Exhaustion Principle and the Practice...

Constitutional Court to prove that there is no other available and/or effective legal remedy. On the other side, the respondent party, in this case the public authority accused of human rights violation, may give its arguments against the applicant's arguments and prove that actually there is an available and effective legal remedy and that the claim ought to be declared inadmissible due to non-exhaustion criterion. After the exhaustion proof is provided the Constitutional Court reserves for itself the right to conclude whether available legal remedies were effective for that particular case ${ }^{8}$.

The Constitutional Court, as a matter of practice, exercises a so-called "balancing test" whereby it requires from the parties to produce evidence pertinent to the exhaustion requirement. In the case No. KI 116/14, the Constitutional Court declared the constitutional referral inadmissible on the grounds of non-exhaustion of all legal remedies because the applicant had failed to make use of the appropriate legal remedy to his availability (Case No. KI116/14, Applicant Fadil Selmanaj). In this case, the Constitutional Court laid down criteria of general nature which would absolve the applicants from exhausting all legal remedies to their avail. The Constitutional Court considered that in order for the applicant to be absolved from the requirement to exhaust all legal remedies it is incumbent on him to show that: (1) the legal remedy was in fact used; (2) the legal remedy was inadequate and ineffective in relation to his case; and (3) there existed special circumstances absolving the applicant from the requirement to exhaust all legal remedies (Ibid.). The Constitutional Court found that the applicant did not meet any of the above-stated criteria in order to be absolved of the requirement to exhaust all legal remedies. Moreover on this point, the Constitutional Court stressed that the applicant in failing to proceed further with the appropriate legal remedy as prescribed by the applicable law in Kosovo is liable to have his case declared inadmissible, as it shall be understood as a waiver of the right to further proceedings on objecting the violation of constitutional rights (Ibid.).

Similarly, in another case No. KI 39/12 the Constitutional Court placed the burden of proof on the applicant by holding that he must prove why he has not exhausted the legal remedies, and show that the legal remedies available to him under Kosovo law were insufficient or unfruitful, or that there were special circumstances which exempted him from the obligation to exhaust such remedies., The Constitutional Court concluded by adding that the applicant's mere doubt does not exempt him from the obligation to exhaust the legal remedies (Case No. KI39/12, Applicant Tomë Krasniqi, paragrhaps 23-24 and 40-44).

In an individual but high profile case No. KI 34/17 (Case No. KI34/17, Applicant Valdete Daka), involving a complaint against the election of the President of the Supreme Court, the Court asked the applicant and the respondent in this case the Kosovo Judicial Council9 to set forth their arguments as to why the applicant should pursue the regular course of exhaustion of

Criteria, Council of Europe/European Court of Human Rights, 2014 on exhaustion requirement. http://www.echr.coe.int/Documents/Admissibility guide_ENG.pdf (referenced on 9 February 2018).

8 See mutatis mutandis cases KI 116/14 Applicant Fadil Selmanaj, Resolution on Inadmissibility of the Constitutional Court of Kosovo of 26 January 2015; KI 39/12, Applicant Tomë Krasniqi, Resolution on Inadmissibility of the Constitutional Court of Kosovo, of 24 July 2012 and KI 56/o9 Fadil Hoxha and 59 Others vs. the Municipal Assembly of Prizren, Judgment of the Constitutional Court of Kosovo, of 22 December 2010. In comparison to practice of the ECtHR on special circumstances availing the obligation to exhaust legal remedies see Judgment on the Merits by the Grand Chamber, Sejdovic v. Italy, No. 56581, 1 March 2006; on cases when there is repetition of acts by authorities contrary to the Convention see Judgment on Merits by a Chamber, Aksoy vs. Turkey, No. 21987/93, 18 December 1996; on cases when the use of legal remedy would be unreasonable in practice hindering proper right to use a remedy, see ECtHR, Judgment on the Merits by a Chamber, Veriter v. France, No. 31508/o7, 14 October 2010.

9 The Kosovo Judicial Council is responsible for recruiting and proposing candidates for appointment and reappointment to judicial office. The Kosovo Judicial Council is also responsible for transfer and disciplinary proceedings of judges, Article 108.3 of the Constitution of Kosovo. 
remedies, instead of granting her direct access to the Constitutional Court, and have the case heard in merits (Ibid., paragraphs 7-20). The applicant, argued that in her case there were no legal remedies that are practical and effective that would provide for a swift resolution of her case in accordance to its nature and specificities (Ibid., paragraph 42). The respondent, on the other hand, argued that the applicant must be required to pursue the regular course of exhaustion of legal remedies in accordance with the applicable provisions of the law on administrative procedure. Ultimately, the respondent required the Court to declare the applicant's complaint as inadmissible on the grounds of her not having exhausted all legal remedies in accordance with the law (Ibid., paragraph 45). The Court then, exercised the "balancing test" based on two premises: (1) whether the legal remedies available to the applicant were accessible and offered reasonable prospects of success; and (2) whether the nature and the specificity of the applicant's complaint warranted the necessity of having her case resolved in a "timely-fashion" (Ibid., paragraph 74). The Court, relying on its previous case-law as well as that of the European Court, found that the applicant must be granted direct access to the Court because the legal remedies available to the applicant do not offer her reasonable prospects of success, the nature and the specificity of the case warranted that that case must be resolved in a "timely-fashion" (Case No. KI99/14 and No. KI100/14, joint decision, Applicants Shyqyri Syla and Laura Pula). The Court also noted that, the respondent merely mentioned that the applicant should pursue the regular course of exhaustion of legal remedies, however, they failed to back-up that assertion with relevant case-law in comparable cases (Case No. KI34/17, Applicant Valdete Daka, paragraph 70).

In the case KI 56/o9 (Case No. KI56/o9, Fadil Hoxha and 59 Others vs. the Municipal Assembly of Prizren), the applicants challenged a decision of the Municipal Assembly of Prizren alleging that the aim of the challenged act is to construct high tower blocks instead of an existing green environment which was foreseen by urban planning (Ibid., paragrahps 3 \& 9). After examining the case, the Constitutional Court noted that the applicants never received any reply from the Municipal Assembly of Prizren pertinent to their right guaranteed by Article $52(2)^{10}$ of the Constitution which establishes that public institutions must take into consideration the opinion of the public on matters that impact the environment on which they live (Ibid., paragrahps 27, 60 \& 67). The Constitutional Court then continued to explain that the applicable law in Kosovo did not provide a legal remedy which would enable the applicants to challenge that act before the regular courts with regard to the right guaranteed by Article 52 (2) of the Constitution ${ }^{11}$. Taking into account the impossibility of the applicants to seek redress before the regular courts, their complaint was declared admissible ${ }^{12}$ (Ibid.).

Similarly in another case, KI 06/10 (Case No. KIo6/10, Valon Bislimi v. Ministry of Interior et al), the Constitutional Court, finding that the applicant had no access to an effective legal remedy, allowed access to it without exhausting legal remedies. In this case, the applicant complained that his right to freedom of movement was violated because authorities of Kosovo were refusing to issue him a passport due to a criminal conviction. The applicant proved that his

\footnotetext{
${ }^{10}$ Article 52 (2) of the Constitution of Kosovo establishes that everyone should be provided an opportunity to be heard by public institutions and have their opinions considered on issues that impact the environment in which they live.

${ }^{11}$ Id, The Constitutional Court of Kosovo, inter alia, reasoned that the Applicants had addressed the Ombudsperson, the Constitutional Court itself and the Ministry of Environment and Spatial Planning in order to seek redress. The Constitutional Court went on to explain the Law on Administrative Dispute that was applicable in Kosovo appeared not to allow for a judicial complaint unless there has been a direct violation of an individual's right or legal interest.

12 The Constitutional Court of Kosovo, found that it is clear that the Decision of 30 April 2009 is not an individual decision; and as such, the Applicants did not have at their disposal a judicial complaint before Supreme Court to challenge the Decision of 30 April 2009 with regard to the right guaranteed by Article 52 of the Constitution. The Law on Administrative Disputes provided no remedy to the Applicants.
} 
constitutional rights were violated by the inaction caused by administrative silence by the Ministry of Interior, he had no possibility to challenge that inaction before the regular courts (Ibid., paragraphs 59-61). Therefore, the Constitutional Court accepted his complaint as admissible, reasoning that the applicant had no access to due and possible effective legal remedies (Ibid., paragraphs 87-99).

Besides formal exhaustion requirements, the substantive exhaustion of legal remedies from the prospective applicants requires that the claim is raised at least in substance concerning the question of constitutionality of a public act with the regular courts. The regular courts of Kosovo have jurisdiction to decide over constitutional claims among points of law and fact when deciding a case (Constitution of Kosovo, Art. 102.3). Thus individuals must invoke their rights guaranteed by the Constitution of Kosovo early in the process or else they risk having their complaints declared inadmissible by the Constitutional Court on the grounds of substantive nonexhaustion. In the case No. KI118/15, (Case No. KI118/15. Applicant Dragiša Stojković) the applicant of Serbian ethnicity complained, inter alia, that the challenged judgment of the Supreme Court violated his right to use of language and to fair and impartial trial, because of an erroneous determination of facts and due to incorrect translation of his statement. The Constitutional Court noted that the applicant, in the course of regular proceedings, has neither raised concretely nor substantially the alleged violation of his right to use Serbian language in the regular proceedings; nor has he explained why he has not invoked in the regular courts his right guaranteed by Article 5 [Languages] of the Constitution in the terms he has presented before the Constitutional Court (Ibid., paragraph 31). The Constitutional Court further emphasized that the applicant should have presented that allegation in his appeal before the regular courts, as he was not only entitled but also obliged to do so in accordance with the principle of subsidiarity. The Constitutional Court declared the complaint inadmissible due to non-exhaustion of all legal remedies as established by Article 113 (7) of the Constitution of Kosovo. The Constitutional Court backed up its conclusion by relying in the well-established case law of the European Court, as well as its own case law in similar matters (Ibid., paragraphs 33-38).

In the above-stated cases, the Constitutional Court showed that it has established a judicial practice pursuant to the principles of the ECtHR on the flexibility of declaring admissible constitutional complaints submitted by individuals where it ascertains that the legal system of Kosovo has not provided them with remedies that are effective and available. The burden of proof falls with the applicant to document that in that particular individual case there are no available and effective legal remedies, while the respondent has the right to claim the opposite. It is in the discretionary power of the Constitutional Court to evaluate evidence provided and come to a conclusion on exhaustion of legal remedies for each particular case. In this respect, the Constitutional Court in its developing case law has consistently maintained that regular judiciary and other public authorities must be given the opportunity to prevent or put right the alleged violation of the Constitution. This approach is based on the assumption that the legal order of Kosovo will provide an effective remedy for the violation of constitutional rights because this is an important aspect of the subsidiary character of the Constitution (Case No. KI41/o9, Applicant AAB-RIINVEST University L.L.C., Prishtina).

The situation may become more complicated where state judiciary represent systemic deficiencies that may be characteristic of states in transition such as Kosovo. In Kosovo, according to statistics available the efficiency of the judiciary is seriously hampered by the shortcomings of criminal legislation; many provisions in the Criminal Procedure Code are too cumbersome and formalistic to permit robust and successful investigation and prosecution. Due to insufficient capacity and staffing and limited financial resources, as well as a heavy backlog of cases, the judicial system is slow in delivering justice (European Commission 2016 Kosovo Progress Report). This raises the awareness of the Constitutional Court when deciding whether legal remedy is available and effective. 


\section{Extraordinary legal remedies and the principle of exhaustion}

As a matter of principle and practice, the so-called extraordinary remedies do not have to be exhausted and the prospective applicants must submit a constitutional complaint with the Constitutional Court within 4 month legal deadline (Constitution of Kosovo, article 49), which starts to run from the day a final decision is issued in regular appeal proceedings. This stance is in line with the stance of the ECtHR which tents to focus on their availability and effectiveness rather than the formal status of the remedy ${ }^{13}$. There are certain extraordinary remedies that are provided for by the law in civil, criminal and administrative proceedings such as the request for reopening of proceedings, request for extraordinary mitigation of punishment in criminal proceedings or the request for protection of legality in civil proceedings which must not be exhausted (Practical Guide on Admissibility Criteria on exhaustion requirement). Those extraordinary remedies are not considered effective by the Constitutional Court because they are not directly accessible to the prospective applicants but depend on the exercise of the discretion by an intermediary such as the state prosecutor ${ }^{14}$. However, for the purposes of a constitutional complaint, if a prospective applicant has made use of such extraordinary remedies, and if that request is accepted by the state prosecutor and is consequently submitted with a regular court on behalf of the applicant the applicant must wait until there is a decision of a regular court pertinent to his or her case. In that situation, the applicant must not simultaneously submit a constitutional complaint with the Constitutional Court because that constitutional complaint shall be deemed premature on the grounds of the principle of subsidiarity (Case No. KI102/16, Applicant Shefqet Berisha).

It must be noted that, there are also certain so-called extraordinary remedies such as the request for "revision" in civil proceedings, the request for "protection of legality" in criminal proceedings and the 'reviewing' in administrative proceedings, which, must be exhausted by the prospective applicants' 15 (Case No. KI135/14, Applicant IKK Classic). One must look beyond the appearances and the naming of such remedies and take stock of their specificities, effectiveness and the realities into which they operate before determining whether a prospective applicant must be required to exhaust them or not ${ }^{16}$ (Criminal Procedure Code). These extraordinary remedies are very similar to an appeal in regular proceedings because: (1) their use depends the discretion of the prospective applicant, and as such, are not depended upon discretion of an intermediary; (2) they are generally used to raise points of law and exceptionally questions of fact as well; (3) the legal deadline to submit them before the regular courts is no longer than two to three months; and, (4) they have proved to be effective remedies, especially, the request for "revision" in civil proceedings, and the request for "protection of legality" in criminal proceedings ${ }^{17}$. Another reason to encourage the prospective applicants to exhaust the so-called extraordinary remedies, which are similar to an appeal in regular proceedings, is that there is a real possibility that they may overlook the regular courts (for example, the Supreme Court) and opt to submit a constitutional

${ }^{13}$ In comparison to ECtHR practice see Judgment on Merits by a Chamber, Tum Haber Sen and Cinar $v$. Turkey, No. 28602/95, 21 February 2006. See also Practical Guide on Admissibility Criteria on exhaustion requirement.

${ }^{14}$ See Law on Contested Procedure No. 03/L-006, Article 245.1, which stipulates that against a final ruling, the public prosecutor might raise the request for legal protection within three months.

${ }^{15}$ See for example, Judgment of the Supreme Court of Kosovo (E. Rev. No. 21/2014, 8 April 2014). However, that judgment was later declared invalid by the Constitutional Court of Kosovo due to deficient reasoning.

${ }^{16}$ Criminal Procedure Code stipulates that a party may request protection of legality within three (3) months of the final judgment or final ruling. The party must file the request with the Basic Court where the final judgment was issued, which shall transmit all validated requests to the Supreme Court.

${ }^{17}$ See conversely, the European Court of Human Rights: Case of Tanase v.Moldova, application No. 7/08, Judgment of 27 April 2010, at paragraph 122 and see mutatis mutandis Decision as to the Admissibility of application No. 32567/o6 by Anne Williams against the United Kingdom. 
complaint with the Constitutional Court instead. However, in reality the Constitutional Court can only review regular proceedings only from the point of view of observance of the constitutional procedure and potential violation of fundamental human rights and freedoms whereas a regular court can review their complaints on the points of law, which is something that the Constitutional Court, in principle, cannot do (Cases No. KI37/17 and No. KI52/17, Applicants Tihomir Mikarić, Olga Janičijević and Shemsïe Sheholli, joint decision, paragraphs 56-57). In addition, a regular court, must also respect the Constitution because that is the obligation and duty imposed by the Constitution on the regular courts and the Constitutional Court as well (Ibid., also Case No. KI135/14, Applicant IKK Classic, paragraph 48).

In a case No. KI159/15 (Applicant Sabri Ferati), where the Constitutional Court was petitioned by an applicant to review decisions of regular courts with respect to his request for reopening of criminal proceedings, the Constitutional Court noted that there were two sets of proceedings in that case (Ibid., paragraph 26). One set of proceedings, the Constitutional Court remarked, was finalized when the applicant was found guilty for having committed the criminal offence of endangering public traffic sanctioned under article 378 of the Criminal Code of Kosovo (Ibid., paragraph 28). The Constitutional Court noted that those proceedings were the main proceedings because they had determined the applicant's criminal responsibility; however, for the purposes of a constitutional complaint, those proceedings were submitted out of time (Ibid., paragraph 30). As far as the second set of proceedings is concerned, with respect to the applicant's request for reopening of criminal proceedings, the Constitutional Court held that the right to a fair and impartial trial is not applicable to those proceedings; and as such, that complaint must be rejected as incompatible ratione materiae with the Constitution because it does not determine the criminal responsibility of the applicant (Ibid., paragraph 37). One must bear in mind, however, that if a request for reopening of proceedings in criminal or civil law is accepted by the regular courts, then the right to a fair trial as guaranteed by article 31 of the Constitution and article 6 of the ECHR can be applicable (ECtHR Case of Sapeyan $v$. Armenia, paragraph 24). Thus, there are general principles, which determine whether a certain remedy must be exhausted or not but the context and the circumstances of a case may determine, in the interest of justice, that the Constitutional Court be flexible and adapt and apply general principles to the case under review.

\section{Conclusion}

Ten years on, the Constitutional Court of Kosovo is pursuing its practice based on the well-established practice of the ECtHR. The legal system of Kosovo made human rights as provided by the ECHR obligatory and superior in their applicability to laws and other acts of public institutions of Kosovo. Furthermore the Constitution of Kosovo made the ECtHR practice as the main reference in interpreting human rights guaranteed by the same Constitution. The Constitutional Court works on the basis of subsidiarity principle. Individuals claiming violation of constitutional rights ought to exhaust legal remedies which are available and effective. Legal remedies must be exhausted not only in formal step-by-step procedure from the first to the last instance of the regular judiciary but they must be exhausted in substance as well. It gives the ordinary judiciary and other public authorities, the opportunity to redress the potential violations of the constitutional rights in individual cases. The rights and freedoms guaranteed by the Constitution and the ECHR must be invoked from the first until the last instance of regular proceedings, and in some cases, like for example in criminal proceedings those rights must be invoked as early as the pre-trial stage.

In its practice the court has established the so called 'balancing test' through which it determines the exhaustion requirement and brings a final decision whether to grant the applicant access to the court when not exhausting legal remedies. The balancing test requires that (1) the legal remedy was in fact used; (2) the legal remedy was inadequate and ineffective in relation to 
his case; and (3) there existed special circumstances absolving the applicant from the requirement to exhaust all legal remedies. The burden of proof lies with the applicant to prove its case of nonexhaustion while the respondent party may advance its arguments against the applicant by proving that in fact there was a legal remedy that is available and effective.

The so-called extraordinary remedies can address questions of law and of constitutionality and sometimes even of facts. Extraordinary legal remedies may not be exhausted nevertheless some extraordinary legal remedies because of their authority may fall within the concept of an available and effective legal remedy. A good example for exhaustion of the extraordinary remedies would be the request for revision in civil proceedings or the request for protection of legality in criminal proceedings because: (1) they are not dependent on an intermediary actor (like the state prosecutor for example); (2) they actually are under the discretion of the prospective applicants; (3) through them the prospective applicants may address their grievances more thoroughly because they can, and in fact must, raise questions of constitutionality, questions of legality and exceptionally even questions of fact; and (4) and they are not subject to uncertain time-limit which would render them ineffective ${ }^{18}$.

\section{Acknowledgements}

This research did not receive any specific grant from funding agencies in the public commercial, or not-for-profit sectors.

The authors declare no competing interests.

\section{Authors}

Mr. Bardh Bokshi works as a Senior Legal Adviser at the Constitutional Court of Kosovo since March 2010, and has finished basic studies (obtained title "Graduated Lawyer" after graduation in an eight semester program) and obtained a master's degree (civil law) in the University of Prishtina-Faculty of Law. Mr. Bokshi has also successfully passed the bar exam organized by the Ministry of Justice of Kosovo, in addition to serving as a lawyer for five months (January-June 2015) for the Albanian Division at the European Court of Human Rights, within the framework of a joint program of the Swiss Embassy in Prishtina, Council of Europe and the Constitutional Court of Kosovo.

Mr. Besfort T. Rrecaj works as Professor of Law, International Law Department at the University of Prishtina "Hasan Prishtina" where he teaches Human Rights, Public International Law and International Organizations. Among other senior positions in public and private sector Mr. Rrecaj has experience with the Constitutional Work in a position of Senior Legal Adviser. His recent work include book chapter titled "Sovereignty vs. R2P: Controlling Hard Law with Soft Law: Not a Great Idea," in Stehphanie Fenkart, Heinz Gartner and Hannes Swoboda ed. Gerechte Intervention? Swischen Gewaltverbot und Schutzverantwortung (Wien, LIT 2017), A Relationship in Limbo: Challenges, Dynamics and Perspective of Kosovo's Integration in NATO, Croatia International Relations Review, XXII (80) 2017, 211-232. For more see http://juridiku.uni-pr.edu/Dekanati/Prodekan-per-qeshtje-mesimore.aspx.

${ }^{18}$ Request for protection of legality must be filed within 3 months of final ruling against which the protection of legality is sought, Article 418.3 of the Code of Criminal Procedure No. 04/L-123. A party may file revision against the ruling of the court of second instance within a time-limit of thirty days. 
B. Bokshi \& B. T. Rrecaj - Ten Years on: The Exhaustion Principle and the Practice...

\section{Acknowledgements}

This research did not receive any specific grant from funding agencies in the public commercial, or not-for-profit sectors.

The authors declare no competing interests.

\section{References}

Case No. KIo6/10, Valon Bislimi v. Ministry of Interior et al, Judgment of the Constitutional Court of Kosovo, of 1 November 2010.

Case No. KI102/16 Applicant Shefqet Berisha, Resolution on Inadmissibility of the Constitutional Court of Kosovo, of 3 March 2017.

Case No. KI116/14, Applicant Fadil Selmanaj, Resolution on Inadmissibility of the Constitutional Court of Kosovo, of 26 January 2015.

Case No. KI118/15 Applicant Dragiša Stojković, Resolution on Inadmissibility of the Constitutional Court of Kosovo, of 27 May 2016.

Case No. KI135/14, Applicant IKK Classic, Judgment of the Constitutional Court of Kosovo, of 9 February 2016.

Case No. KI159/15, Applicant Sabri Ferati, Resolution on the Inadmissibility of the Constitutional Court of Kosovo, of 14 June 2016.

Case No. KI34/17, Applicant Valdete Daka, Judgment of the Constitutional Court of the Kosovo, of 12 June 2017.

Case No. KI39/12, Applicant Tomë Krasniqi, Resolution on Inadmissibility of Constitutional Court of Kosovo, of 24 July 2012.

Case No. KI41/o9 Applicant AAB-RIINVEST L.L.C., Resolution on Inadmissibility of the Constitutional Court of Kosovo, of 3 February 2010.

Cases Nos. KI37/17 and KI52/17, Applicants Tihomir Mikarić Olga Janičijević and Shemsije Sheholli, Joint Resolution on Inadmissibility of the Constitutional Court of Kosovo, of 1 November 2017.

Cases No. KI99/14 and KI100/14, Applicants Shyqyri Syla and Laura Pula, Joint Judgment of the Constitutional Court of Kosovo, of 8 July 2014.

Code of Criminal Procedure No. 04/L-123.

Constitution of Kosovo (Constitution, K-09042008, Assembly of Kosovo, 9 April 2008, and its amendments, Official Gazette).

ECtHR Case Aksoy vs. Turkey, Application no. 21987/93 Judgment on the Merits by a Chamber, 18 December 1996.

ECtHR Case Dalia v. France, Application no. 26102/95, Judgment on the Merits delivered by a Chamber, 19 February 1998.

ECtHR Case of Anne Williams against the United Kingdom, Application no. 32567/o6, ECtHR, Decision as to the Admissibility.

ECtHR Case of Sapeyan v. Armenia, Application no. 35738/o3, ECtHR, Judgment of 13 January 2009.

ECtHR Case of Tanaše v. Moldova, Application no. 7/o8, ECtHR, Judgment of 27 April 2010.

ECtHR Case Sejdovic v. Italy, Application no. 56581, Judgment on the Merits by the Grand Chamber, 1 March 2006. 
ECtHR Case Tum Haber Sen and Cinar v. Turkey, Application no. 28602/95, Judgment on the Merits by a Chamber, 21 February 2006.

ECtHR Case Veriter $v$. France, Application no. 31508/o7, Judgment on the Merits by a Chamber, 14 October 2010.

European Commission, 2016 Kosovo Progress Report, Communication from the Commission to the European Parliament, the Council, the European Economic and Social Committee and the Committee of the Regions. SWD (2016) 363 final. (European Commission, Brussels, 9 November 2016).

Law on Contested Procedure No. 03/L-006.

Law on the Constitutional Court of Kosovo No. 03/L-121.

Practical Guide on Admissibility Criteria, Council of Europe/European Court of Human Rights, 2014. http://www.echr.coe.int/Documents/Admissibility guide ENG.pdf (accessed on 9 February 2018). 
B. Bokshi \& B. T. Rrecaj - Ten Years on: The Exhaustion Principle and the Practice...

C O A $\mathbf{s}$ 